DOI: $10.1515 / \mathrm{sjdv}-2017-0008$

\title{
Distinguishing a Rare Variant of Lipidized Dermatofibroma from Nonlipidized Dermatofibromas in a Patient with Hypothyroidism and Alopecia Areata
}

\author{
Farah ABDULLA ${ }^{1,2}$, Heather PECK', Ashley FENERAN ${ }^{1}$, Ashley JENKINS ${ }^{1,}$ * and Katherine
} MULLERSMAN ${ }^{2}$

University of Chicago Hospital Medical Center, IL

${ }^{1}$ Section of Dermatology

2University of Chicago Pritzker School of Medicine, IL

*Correspondence: Ashley M. Jenkins, MD, University of Chicago Medicine, Section of Dermatology, 5841 S. Maryland Ave., MC 5067, Chicago, IL 60637, Email: Ashley.Jenkins@uchospitals.edu

UDC 616.5-006-091.8:616.594.1

UDC 616.5-006-091.8:616.441-008.64

\begin{abstract}
Introduction. Lipidized dermatofibromas represent rare and often underrecognized variants of dermatofibromas. Histologically, dermatofibromas are composed of fibroblast-like spindle cells, foam cells, giant cells, siderophages, lymphocytes, capillaries, collagen fibers, and hyaline dermal collagen fibers. Lipidized dermatofibromas are characterized by numerous foam cells, Touton giant cells, and hyalinized wiry collagen in the stroma. Case report. We present a case of a 31-year-old woman with a history of hypothyroidism and alopecia areata, presenting with an enlarging $8 \mathrm{~mm}$, firm erythematous nodule on her upper-mid back. Biopsy examination showed a cellular proliferation of spindle cells with peripheral collagen trapping and cholesterol clefts with associated foam cells and sclerosis, staining weakly positive for Factor XIIla and negative for CD34. The diagnosis of a benign lipidized dermatofibroma was rendered. Conclusion. Lipidized dermatofibromas are rare histologic variants of dermatofibromas, biologically indolent, and should be distinguished from other cutaneous foamy histiocytic lesions, particularly xanthomas, which may alter patient management.
\end{abstract}

Key words: Histiocytoma, Benign Fibrous; Skin Neoplasms; Diagnosis; Treatment Outcome; Comorbidity

\section{Introduction}

Lipidized dermatofibroma is a rare variant of dermatofibromas. The prevalence of this variant in the general population is unknown, but some evidence suggest that it is as low as $2.1 \%$ in different dermatofibroma types (1). Lipidized dermatofibroma was described by Iwata as "ankle-type" dermatofibroma (fibrous histiocytoma) due to its characteristic location on the lower extremities (2). Subsequent evaluation by Wagamon demonstrated no significant difference in location between nonlipidized and lipidized dermatofibromas (3). Lipidized dermatofibromas are histologically characterized by an abundance of foam cells and stromal wiry hyalization (2). A case of a lipidized dermatofibro$\mathrm{ma}$ is reported herein, and the significance of this rare pathological variant is discussed.

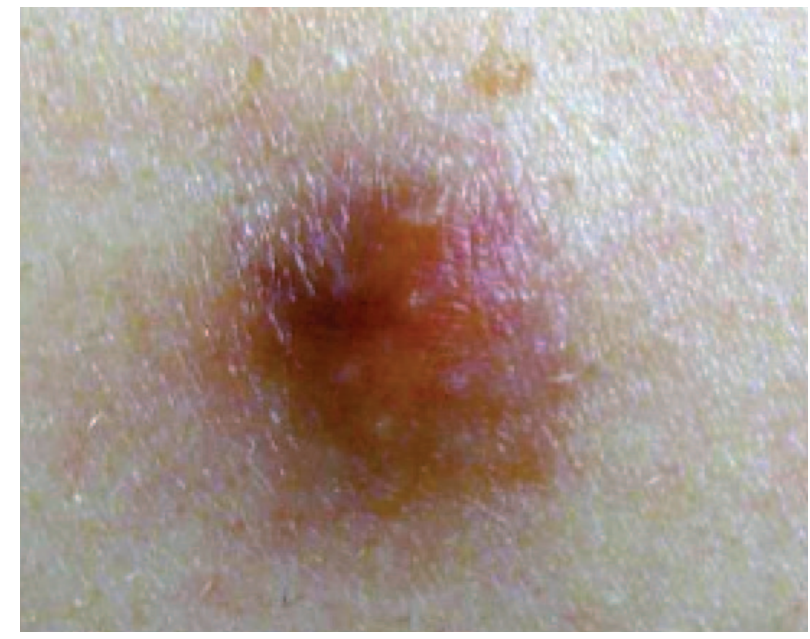

Figure 1. Upper back with $0.8 \mathrm{~cm}$ firm, erythematous, dome shaped nodule 


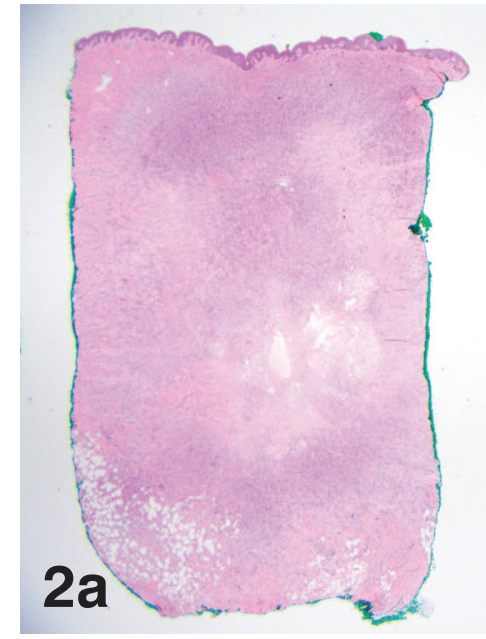

Figure 2a. Punch biopsy at $4 x$ demonstrating a mildly acanthotic epidermis with a basophilic cellular infiltrate in the dermis extending into subcutis

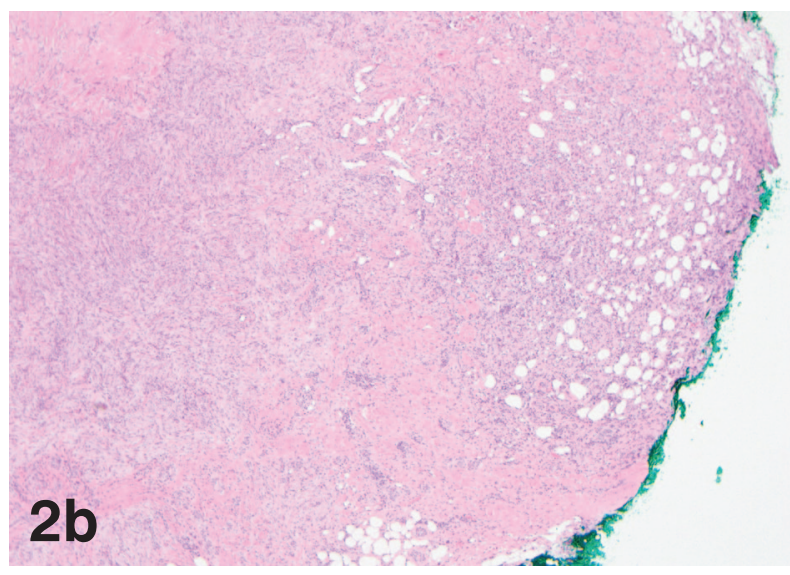

Figure 2b. $10 \mathrm{x}$ demonstrating spindle cells with peripheral collagen trapping. The central aspect of the spindle cell proliferation contained cholesterol clefts with associated foam cells and sclerosis

\section{Case Report}

A 31-year-old woman with a history of hypothyroidism and alopecia areata presented with an enlarging $8 \mathrm{~mm}$, firm erythematous nodule on her upper-mid back (Figure 1). The intermittently tender nodule had been present for over ten years. An $8 \mathrm{~mm}$ punch biopsy was performed from the central portion of the nodule. Histological evaluation revealed a mild epidermal acanthosis (Figure 2A). Within the dermis and extending into the subcutis, there was a cellular proliferation of spindle cells with peripheral collagen trapping (Figures 2B, C). The central aspect of

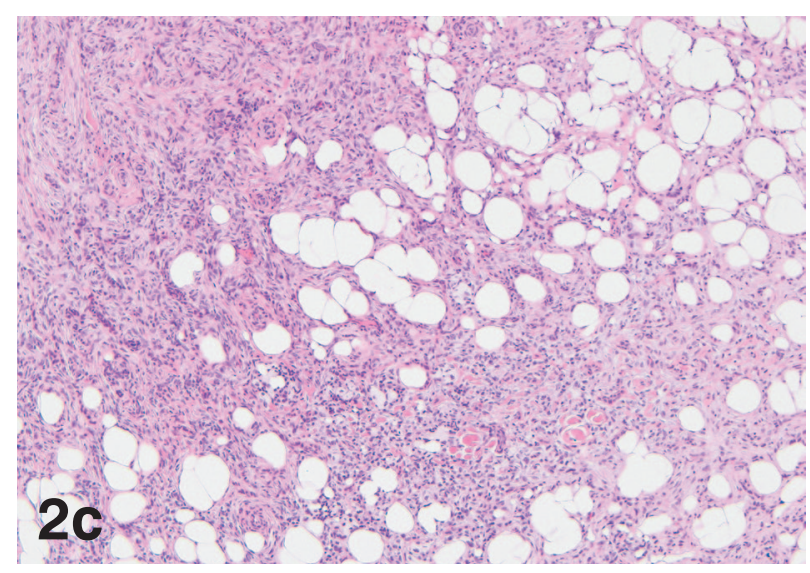

Figure 2c. $40 \times$ no significant cytologic atypia or mitotic activity was identified

the spindle cell proliferation contained cholesterol clefts with associated foam cells and sclerosis (Figure 3). No significant cytologic atypia or mitotic activity was identified. The sample stained weakly positive for Factor XIIIA within the spindle cell proliferation (Figure 4). It stained negatively for CD34 in the central aspect of spindle cell proliferation and positively along the periphery (Figure 5). The diagnosis of a benign lipidized dermatofibroma was rendered. Three month follow up showed no recurrence.

\section{Discussion}

Lipidized dermatofibromas represent a rare and often underrecognized variant of dermatofibromas. Histologically, dermatofibro-

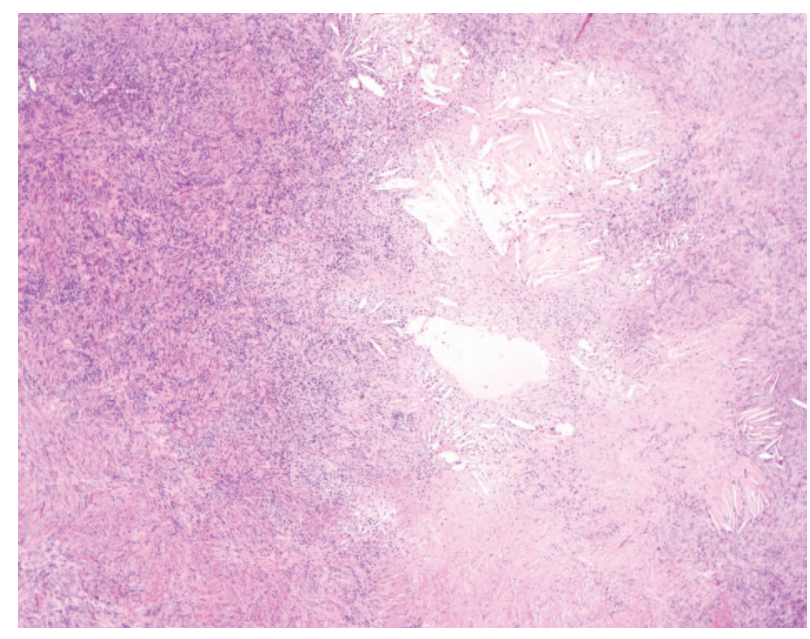

Figure 3. $40 \mathrm{x}$ spindle cell proliferation containing cholesterol clefts 


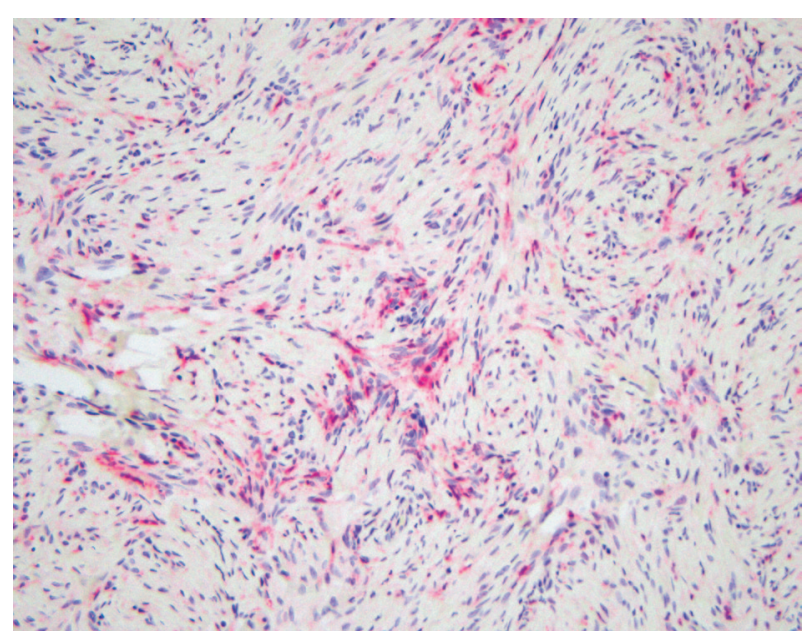

Figure 4. Factor XIIIA stain weakly positive within the spindle cell proliferation

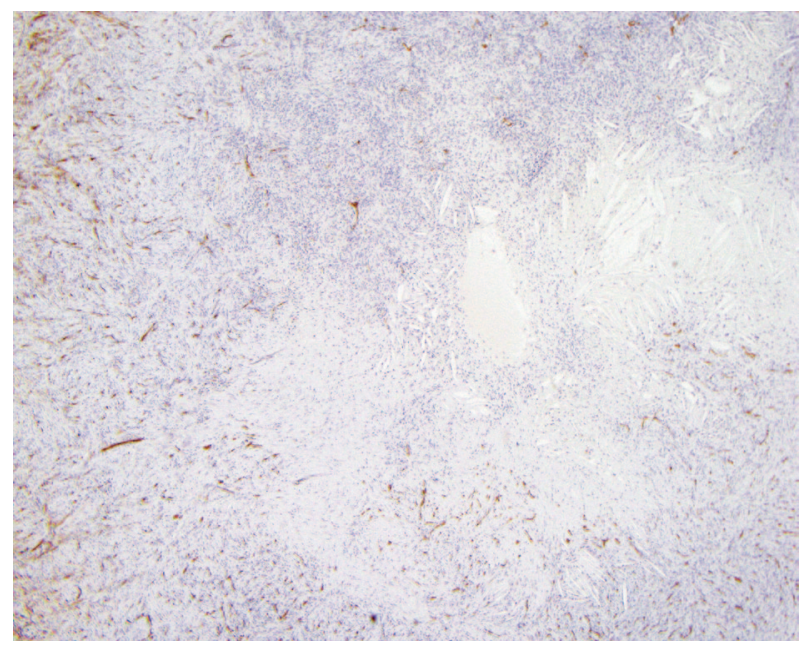

Figure 5. CD34 stain negative in the central aspect of spindle cell proliferation and positive along the periphery

mas are composed of a mixture (in varying proportions) of fibroblast-like spindle cells, as well as foam cells, giant cells, siderophages, lymphocytes, capillaries, collagen fibers, and entrapping hyaline dermal collagen fibers (4). Lipidized dermatofibromas are most remarkable for numerous foam cells and frequent Touton-type giant cells, as well as hyalinized wiry collagen in the stroma, which can sometimes be extensive (5).

Wagamon et al. (3) conducted a retrospective case review to investigate the relationship between lipidized dermatofibromas and patient age, anatomic location, and total serum cholesterol. They determined that patients with lipidized dermatofibromas did not differ significantly from patients with regular dermatofibromas in regard to age, tumor location, or underlying serum lipid levels.

\section{Conclusion}

Lipidized dermatofibroma is a rare histological variant of dermatofibromas, biologically indolent, which should be distinguished from other cutaneous foamy histiocytic lesions, particularly xanthomas, which may alter patient management.

\section{References}

1. Alves JV, Matos DM, Barreiros HF, Bartolo EA. Variants of dermatofibroma - a histopathological study. An Bras Dermatol. 2014;89(3):472-7.

2. Iwat J, Fletcher CD. Lipidized fibrous histiocytoma: clinicopathologic analysis of 22 cases. Am J Dermatopathol. 2000;22(2):126-34.

3. Wagamon K, Somach SC, Bass J, Sigel JE, Xue W, Schluchter M, et al. Lipidized dermatofibromas and their relationship to serum lipids. J Am Acad Dermatol. 2006;54(3):494-8.

4. Luzar B, Calonje E. Cutaneous fibrohistiocytic tumours - an update. Histopathology. 2010;56(1):148-65.

5. Zelger B, Zelger BG, Burgdorf WH. Dermatofibroma-a critical evaluation. Int J Surg Pathol. 2004;12(4):333-44.

\section{Razlikovanje retke varijante lipidizovanih od nelipidizovanih dermatofibroma kod pacijentkinje sa hipotiroidizmom i alopecijom areata}

\section{Sažetak}

Uvod. Lipidizovani dermatofibrom predstavlja retku i često nedovoljno prepoznatu varijantu dermatofibroma. Histološki, dermatofibromi se sastoje od fibroblastnih vretenastih ćelija, penastih ćelija, gigantskih ćelija, siderofaga, limfocita, kapilara, kolagenih vlakana i hijalinskih kožnih kolagenih vlakana. Lipidizovane der- 
matofibrome karakterišu brojne penaste ćelije, džinovske ćelije tipa Touton i hijalinski čvrst kolagen u stromi. Prikaz slučaja. Predstavljamo slučaj 31-godišnje žene sa istorijom hipotiroidizma i alopecije areata. Primljena je sa čvrstim eritematoznim nodulom na gornjoj polovini leđa prečnika $8 \mathrm{~mm}$. Biopsija ispitivanog uzorka pokazala je ćelijsku proliferaciju vretenastih ćelija sa perifernom pojavom kolagena, holes- terola sa penastim ćelijama, sa slabim pozitivnim bojenjem za faktor XIIla i negativnim za CD34. Postavljena je dijagnoza benignog lipidizovanog dermatofibroma. Zaključak. Lipidizovani dermatofibromi su retke histološke varijante dermatofibroma, biološki indolentni, i treba ih razlikovati od drugih akutnih penastih histiocitnih lezija, posebno ksantoma, što može promeniti lečenje pacijenata.

Ključne reči: Benigni fibrozni histiocitom; Kožne neoplazme; Dijagnoza; Ishod terapije; Komorbiditet 